\title{
Nutritional Quality of Tomato (Lycopersicon esculentum Mill) as Influenced by Mulching, Nitrogen and Irrigation Interval
}

\author{
Aliyu Samaila (Corresponding author) \\ Nigerian Agricultural Extension and Research Liaison Services \\ Ahmadu Bello University, Zaria 810001, Nigeria \\ Tel: 803-700-2812 E-mail: papakama197@yahoo.com;asamaila@nigeriamarkets.org \\ Ezra Bako Amans, Ibrahim Umar Abubakar \& Bashir Ahmad Babaji \\ Department of Agronomy, Ahmadu Bello University, Zaria 810001, Nigeria
}

\begin{abstract}
An experiment was conducted in 2006/07 dry season to evaluate the effect of mulching, nitrogen and irrigation interval on the nutritional quality of Tomato (Lycopersicon esculentum Mill) at Shika, Nigeria. Treatments consisted of three mulching (no mulch, rice-straw mulch and black polythene mulch) four nitrogen rates $(0,45$, 90 and $\left.135 \mathrm{kgN} \mathrm{ha}^{-1}\right)$ and three irrigation intervals (5, 10 and 15 days). Mulching significantly increased the dry matter, protein and carbohydrate contents in fruits, but decreased the crude fiber content. In most cases rice-straw mulch appeared a better mulching material. $\mathrm{N}$ rate of $45 \mathrm{~kg} \mathrm{ha}^{-1}$ had more dry matter content over control, but higher values for protein and carbohydrate contents were with $90 \mathrm{~kg} \mathrm{ha}^{-1}$. The $135 \mathrm{kgN} \mathrm{ha}^{-1}$ rate depressed carbohydrate content. Irrigation interval of 10 days recorded more dry matter and crude fiber while highest fruit carbohydrate contents was attained at 15 day irrigation interval over the 5-day interval. Delaying irrigation significantly depressed fruit protein content. Rice-straw mulch $+90 \mathrm{kgN} \mathrm{ha}^{-1}$ or polythene mulch in combination with $45 \mathrm{kgN} \mathrm{ha}^{-1}$ had more carbohydrate in fruits.
\end{abstract}

Keywords: Tomato, Quality, Nutrition, Mulching, Nitrogen

\section{Introduction}

Tomato is an important vegetable condiment used for stew and other recipes in Nigeria. Its production in the savanna zone of Nigeria is mainly during the dry season when it has to be fully supported by irrigation (Anon, 2000). It is the most widely grown vegetable crop under irrigation but lack of water is limiting production and expansion (Ramalan, 1994). Mulching is used principally as moisture is conservation practice which not only reduces the number of irrigations required but has other benefits like increasing the root zone temperature and improving the nutrient uptake. Performance of tomato under mulch is dependent on mulching material (Hunter et al.,1991, Amans et al., 2008, Teasdale and Abdul-Baki, 1995). The advantages of mulching were evident in not only increasing the total fruit yield of tomato, but also in the yields of unblemished fruits(Abdul-Baki and Spence, 1992, Wein et al.,1993)

Water is essential for the physiological activity of tomato and in sufficient water at any stage will affect the yield and quality but, too much water results in flooding and poor growth, while too little water reduces quality (Hanson et al., 2001). The common irrigation practice in the region is a seven-day interval (Ramalan et al., 1998), this also depends on the soil type and its moisture retention capacity, water availability and rate of air movement. Water application by means of irrigation increased the higher marketable yields in tomato due to increase in freshness of fruits (Imtiyaz et al., 2000). Elkner and Kanizweiski (1999) however, reported a decrease in the amounts of carbohydrates, fiber and nitrates in fruits, and increase in fruit weight compression resistance and marketable yield in irrigated plants compared to non-irrigated ones.

Tomato is a heavy feeder and nitrogen is not only essential for its growth and development, but plays an important role in the biosynthesis of its fruit constituents; too much nitrogen has however been reported to affect the post-harvest qualities of tomato fruits (Upendra et al., 2000). Nongkas,(1995),reported an increase in the brix and firmness of tomato with a decrease in nitrogen rates, while Parisi et al (2003), reported a high increase of unmarketable fruit yields with nitrogen rates of $250 \mathrm{~kg} / \mathrm{ha}^{-1}$ Extraneous application of nitrogen in form of fertilizer is essential in the savanna soils of Nigeria which are characterized by poor fertility and thus, low 
nitrogen content (Quinn, 1980). Therefore, any factor that will enhance moisture and nutrients availability and retention will certainly go a long way in improving tomato fruit quality. It is in view of the above facts that the study was carried out with the following objective:

To assess the nutritional composition of tomato grown under mulch types, varying nitrogen rates and different irrigation intervals

\section{Material and Methods}

The trial was conducted during the $2006 / 07$ day seasons at Shika $\left(11^{\circ} 12^{\prime}, 7^{\circ} 33^{\prime} \mathrm{E}\right.$ and $610 \mathrm{~m}$ above sea level) in the Northern Guinea Savanna of Nigeria. The soil was silt-loam with samples taken randomly at $30 \mathrm{~cm}$ depth before the trial and analyzed for physico-chemical properties (Table 1).

Treatments consisted of three mulch types (no mulch, rice-straw mulch and black polythene mulch), four nitrogen fertilizer rates $\left(0.45,90\right.$ and $\left.135 \mathrm{~kg} \mathrm{ha}^{-1}\right)$ and three irrigation intervals $(5,10$ and 15days). They were arranged in a split plot design with factorial combinations of nitrogen and irrigation in the main plot and mulching in the sub-plot, and replicated three times.

The land was harrowed and prepared into sunken beds of $3.75 \times 3 \mathrm{~m}\left(11.25 \mathrm{~m}^{2}\right)$ separated by $0.75 \mathrm{~m}$ irrigation channels. All beds received an equivalent of 20 and $37 \mathrm{~kg} \mathrm{ha}^{-1}$ of $\mathrm{P}$ and $\mathrm{K}$ during land preparation. The black polythene mulch was laid over the entire bed and water was applied over it to make it stick. Transplanting holes of $60 \mathrm{~cm}$ spacing were then punched and six weeks old seedlings UC-82B variety of tomato were thereafter planted into the holes and covered with sand. Rice-straw $5 \mathrm{~cm}$ thick was laid to cover all the open spaces in the straw treatments. All fertilizer treatments received and equivalent of $45 \mathrm{kgN} \mathrm{ha}^{-1}$ in form of Urea one week after transplanting, and the remaining doses as per treatment requirement were applied in split applications at three and six weeks after transplanting.

All plots were uniformly watered by flooding of basins for the first two weeks after which the irrigation interval treatment was imposed. Weeds were controlled using hoe in the bare plots while they were hand pulled in the straw-mulched plots.

Tomato fruits were harvested when ripe and five fruit samples were taken from each plot, made into a paste and analyzed for:

\subsection{Dry matter content}

The five fruit samples were made into a paste and weighed before being oven dried at $105^{\circ} \mathrm{C}$. The moisture percentage was then determined by the difference in weights before and after oven drying. The balance was the fruit dry matter percentage (A.O.A.C., 1980).

\subsubsection{Crude fiber content}

This was determined by subjecting the sample paste to simultaneous acid-base treatments, cooled in a desiccator and weighed to determine the percentage crude fiber content (A.O.A.C., 1980).

\subsubsection{Protein content}

The protein content was determined by the Kjeldahl method. The sample was mixed with sulphuric acid in the presence of a catalyst to digest the organic matter present. Ammonia was then liberated after distillation protein was calculated as $\mathrm{CP}=6.25 \mathrm{x} \% \mathrm{~N}$ (A.O.A.C., 1980).

\subsubsection{Percent Carbohydrate}

Carbohydrate is the nitrogen free extract and was calculated as NFE - $100-($ Crude protein + moisture + Crude fiber).(A.O.A.C.,1980)

The data collected were subjected to statistical analysis and means were compared using Duncan's Multiple Range Test (Duncan,1955).

\section{Results}

Mulching effect was significant on dry matter and fiber content (Table 2). Mulched tomato plants produced fruits with more dry matter in them than the un-mulched plants. Between the mulching materials, fruits from rice-straw mulch had more dry matter in fruits than those from polythene- mulched plants. There was significantly more crude fiber in un-mulched tomato while there was no significant difference in crude fiber contents of tomato mulched with either polythene mulch or rice-straw mulch.

Application of $\mathrm{N}$-fertilizer significantly increased the dry matter content in fruits over control. There was however no significant difference in the rates applied. The fiber content increased only with the $\mathrm{N}$ rate was 
raised from 45 to $90 \mathrm{~kg} \mathrm{~N} \mathrm{ha}^{-1}$; beyond this rate the fiber content remained unaffected.

Irrigating at 10 days interval produced more dry matter and crude fiber in fruits than the 5-day irrigation interval. Values for 10 and 15 days irrigation interval were statistically at par.

Mulching significantly increased both fruit protein and carbohydrate contents over un-mulched tomato (Table 3.) While there was no significant difference in protein content of tomato mulched with polythene or rice-straw mulch. Tomato mulched with rice-straw produced more carbohydrate than the one mulched with polythene.

Application of nitrogen significantly increased the contents of protein and carbohydrate over control. The increase was however only up to higher rate of $90 \mathrm{kgN} \mathrm{ha}^{-1}$. Carbohydrate content thereafter depressed at the highest $\mathrm{N}$ rate of $135 \mathrm{kgN} \mathrm{ha}^{-1}$.

Increasing the irrigation interval from 5 to 10 and further to 15 days had significantly decreased and increased tomato fruit protein and carbohydrates contents, respectively.

An interaction between mulching and $\mathrm{N}$ fertilizer rates on the carbohydrate content of tomato was observed (Table 4). Application of $45 \mathrm{kgN} / \mathrm{ha}^{-1}$ to un-mulched tomato increased the fruit carbohydrate content, while rates above $90 \mathrm{~kg} / \mathrm{ha}^{-1}$ reduced the fruit carbohydrate content. Tomato under straw mulch produced more carbohydrate with the application of $90 \mathrm{kgN} / \mathrm{ha}^{-1}$. Under polythene mulch however, increase in carbohydrate content was with $45 \mathrm{kgN} / \mathrm{ha}$ rate. The higher rates depressed carbohydrate contents.

\section{Discussion}

Mulching had a significant impact on fruit dry matter, protein and carbohydrate which were all better under mulch than in bare plots. Irrespective of the mulching material used, the beneficial aspects of mulching in moisture preservation, ambient below ground environment and general better performance of tomato under mulch (Amans et al., 2008, Teasdale and Abdul-Baki, 1995, Hanson et al., 2001) were clearly demonstrated in this experiment.

The critical role nitrogen plays in the nutrition of tomato and the subsequent quality of its fruits was also obvious in this experiment. In the case of dry matter content of the fruits, $\mathrm{N}$-rate as low as $45 \mathrm{~kg} / \mathrm{ha}$ made a significant difference over control. In the synthesis of protein and carbohydrate however, the need for higher N-rate up to 90 $\mathrm{kgN}$ ha ${ }^{-}$was exhibited (Upendra et al., 2000, Nongkas, 1995). This is in spite of the fact that the soil was fairly rich in nitrogen $(0.18 \%)$

Most of the parameters considered (dry matter and crude fiber) were optimized with a 10 day irrigation interval, while carbohydrate and protein contents peaked with 15 and 5-day intervals, respectively. This indicates that though the general practice in the region is a seven-day interval (Ramalan et al., 1998), water can be saved by delaying irrigation to 10 or even to some extent 15 days and achieve optimum results. But this has to depend on both the climatic and edaphic factors of the area.

The interaction between mulching and fertilizer also showed that applied fertilizer was better utilized under straw mulch, a position earlier reported (Teasdale and Abdul-Baki, 1995, Abdul-Baki and Spence, 1992) that the straw mulch allows for better air-circulation and it results in better overall performance of tomato.

\section{Conclusion}

This study confirms the valuable contribution of mulching nitrogen and irrigation on nutritional quality of tomato. The rice-straw mulch being cheaper, more available and easier to lie has proved more beneficial while the $90 \mathrm{~kg} \mathrm{~N} \mathrm{ha}{ }^{-1}$ rate of fertilizer and a 10-day irrigation interval also produced the best quality tomato fruits.

\section{References}

A.O.A.C. (1980). Official methods of analysis, $12^{\text {th }}$ edition. Association of Official Analytical Chemists, Washington DC.

Amans E.B, Shebayan J.A.Y and Miko S. (2008). The influence of mulch and plant density on the production of irrigated tomato (Lycopersicon esculentum Mill) under conditions of high water table at Kadawa. Paper presented at the $26^{\text {th }}$ annual conference of the Horticultural Society of Nigeria,Mubi,Adamawa State, $26-30^{\text {th }}$ October, 2008.

Anonymous. (2000). Growing Tomatoes in Nigeria. Commercial Crop Guide series. United States Agency for International Development;USAID and Information communication for Agricultural Growth I Nigeria pp1-4.

Duncan D.B. (1955). Multiple Range and Multiple E-test Biometrics II (1955):pp1-42.

Elkner,K and Kanieszweiski, S.C. (1999). Effects of drip irrigation and mulching on quality of tomato fuits. Acta 
Horticulturae 379: International Symposium on quality of fruits and vegetables: Influence of post-harvest factors and technology.

Hanson P, Chen J.J, Kuo C.G, Morris R and Opena R.T. Tomato Production. (2001). In AsianVegetable Research and Development Center training manual.

Hunter J. Jr, Pittenger D and Voss R. (1991). Saving Water in Vegetable Gardens. Vegetable Research and Information Center, University of California. 1991. pp1-3.

Imtiyaz, M. Mgalda, N.P, Chepete, B and Manase, S.K. (2000). Response os six vegetable crops to irrigation schedules. Agricultural Water Management, 45:331-342

Nongkas, A. (1995). Fertilizer and mulching trials on Processing Tomato. Asian Regional Center. Research Report pp5.

Parisi, M, Giordano, A. Pentangelo, A. D’Onofrio, B. and ViMari, G. (2003). Effects of different levels of Nitrogen fertilization on yield and fruit quality in processing tomato. ISHS Acta Horticulturae 700: International symposium: Towards Ecologically Sound fertilization Strategies for field vegetable production.

Quinn J. G.. (1980). A review of tomato cultivar trial in the Northern States of Nigeria. In Samaru Miscellaneous Paper: 84. Institute for Agricultural Research, Ahmadu Bello University, Zaria.

Ramalan A.A. (1994). Irrigation and Environment: The state of Research and Development at the Institute for Agricultural Research, IAR, Samaru. NOMA Magazine, 1994(11):16-19.

Ramalan A.A, Dadari S.A, and Voh J.P. (1998). Crop production and management: Irrigation Research Trend In: Proceedings of the $12^{\text {th }}$ National Irrigation and Drainage Seminar: Irrigation in sustainable agriculture: Institute of Agricultural Research Samaru, Ahmadu Bello University, Zaria, Nigeria pp15-28

Teasdale J.R and Abdul-Baki A.A. (1995). Soil temperature and tomato growth associated with Black polythene and Hairy Vetch Mulches. Journal of the American Society for Horticultural Science, (120): 706-882.

Upendra M.S, Ramdane D and Bharat S. (2000). Mineral Nutrition in Tomato: Food, Agriculture and Environment. Vol 1 no 2; 176-183.

Wein, H.C, Minotti, P.L. and Grubinger, V.P. (1993). Polythene mulch stimulates early root growth and nutrient uptake in transplanted tomatoes. Journal of American Society for Horticultural Science, 118:170-324

Table 1. Physico-chemical characteristics of soil taken from experiment site 2006/07

\begin{tabular}{|l|l|}
\hline Particle size distribution $(\mathrm{g} / \mathrm{kg})$ & \\
\hline Sand & 36 \\
\hline Silt & 53 \\
\hline Clay & 14 \\
\hline Texturalclass & Silt-loam \\
\hline Chemical properties & \\
\hline PH in $\mathrm{H}_{2} \mathrm{O}$ & 5.58 \\
\hline Pin Cacl $1: 25$ & 5.25 \\
\hline Organic carbon $(\mathrm{g} / \mathrm{kg})$ & 0.66 \\
\hline Available $\mathrm{P}(\mathrm{g} / \mathrm{kg})$ & 0.04 \\
\hline \%Total nitrogen & 0.18 \\
\hline Exchangeable cations $(\mathrm{g} / \mathrm{kg})$ & \\
\hline $\mathrm{K}$ & 0.30 \\
\hline $\mathrm{Mg}$ & 0.67 \\
\hline $\mathrm{Ca}$ & 1.7 \\
\hline $\mathrm{Na}$ & 0.50 \\
\hline $\mathrm{CEC}$ & 6.50 \\
\hline
\end{tabular}

Source: Analyzed soil samples at Agronomy department's laboratory, A.B.U. Zaria 
Table 2. Effect of mulching, nitrogen and irrigation on dry matter in fruits and fiber content of tomato in 2006/07 dry season at Shika

\begin{tabular}{|l|l|l|}
\hline Treatments & Dry matter of fruits (\%) & Fiber content (\%) \\
\hline Mulching (M) & & \\
\hline No mulch & $5.7 \mathrm{c}$ & $0.8 \mathrm{a}$ \\
\hline Rice-straw mulch & $6.8 \mathrm{a}$ & $0.7 \mathrm{~b}$ \\
\hline Polythene mulch & $6.2 \mathrm{~b}$ & $0.7 \mathrm{~b}$ \\
\hline SE+- & 0.10 & 0.03 \\
\hline Nitrogen (N) kg ha & & \\
\hline 0 & & \\
\hline 45 & $5.7 \mathrm{~b}$ & $0.7 \mathrm{~b}$ \\
\hline 90 & $6.5 \mathrm{a}$ & $0.7 \mathrm{~b}$ \\
\hline 135 & $6.5 \mathrm{a}$ & $0.8 \mathrm{a}$ \\
\hline SE+- & $6.3 \mathrm{a}$ & $0.8 \mathrm{a}$ \\
\hline Irrigation (days) & 0.08 & 0.07 \\
\hline 5 & & \\
\hline 10 & $5.9 \mathrm{~b}$ & $0.7 \mathrm{~b}$ \\
\hline 15 & $6.9 \mathrm{a}$ & $0.8 \mathrm{a}$ \\
\hline SE+- & $6.9 \mathrm{a}$ & $0.8 \mathrm{a}$ \\
\hline Interaction & 0.06 & 0.06 \\
\hline M x N & & \\
\hline M I & NS & NS \\
\hline N x I & NS & NS \\
\hline M x N x I & NS & NS \\
\hline
\end{tabular}

Means followed by the same letter(s) within a column and treatment set are not significantly different when using DMRT $(\mathrm{P}=0.05)$, NS=Not significant

Table 3. Effect of mulching, nitrogen and irrigation on percentage protein and carbohydrate contents of tomato in 200/07 dry season at Shika

\begin{tabular}{|l|l|l|}
\hline Treatments & Protein (\%) & Carbohydrate(\%) \\
\hline Mulching (M) & & \\
\hline No mulch & $0.7 \mathrm{~b}$ & $3.6 \mathrm{c}$ \\
\hline Rice-straw mulch & $1.2 \mathrm{a}$ & $5.9 \mathrm{a}$ \\
\hline Polythene mulch & $1.2 \mathrm{a}$ & $4.0 \mathrm{~b}$ \\
\hline SE+- & 0.04 & 0.03 \\
\hline Nitrogen (N) kg ha & & \\
\hline 0 & & \\
\hline 45 & $1.1 \mathrm{c}$ & $4.0 \mathrm{~d}$ \\
\hline 90 & $1.8 \mathrm{~b}$ & $4.7 \mathrm{~b}$ \\
\hline 135 & $2.2 \mathrm{a}$ & $5.0 \mathrm{a}$ \\
\hline SE+- & $2.2 \mathrm{a}$ & $4.4 \mathrm{c}$ \\
\hline Irrigation (days) & 0.04 & 0.06 \\
\hline 5 & & \\
\hline 10 & $1.2 \mathrm{a}$ & $4.0 \mathrm{c}$ \\
\hline 15 & $0.6 \mathrm{~b}$ & $4.9 \mathrm{~b}$ \\
\hline SE+- & $0.3 \mathrm{c}$ & $5.3 \mathrm{a}$ \\
\hline Interaction & 0.03 & 0.02 \\
\hline M x N & & \\
\hline M x I & NS & $* *$ \\
\hline N x I & NS & NS \\
\hline M x N x I & NS & NS \\
\hline
\end{tabular}

Means followed by the same letter(s) within a column and treatment set are not significantly different when using DMRT $(\mathrm{P}=0.05), \mathrm{NS}=$ Not significant, $* *=$ highly significant

Table 4. Interaction between mulching and fertilizer on carbohydrate content of tomato in 2006/07 dry season at Shika

\begin{tabular}{|l|l|l|l|l|}
\hline & \multicolumn{5}{|l|}{ Fertilizer $\left(\mathbf{k g ~ h a}^{-1}\right)$} \\
\hline Treatments & 0 & 45 & 90 & 135 \\
\hline Mulching (M) & \multicolumn{5}{|l|}{} \\
\hline No mulch & $2.4 \mathrm{~d}$ & $4.5 \mathrm{~b}$ & $4.2 \mathrm{~b}$ & $3.1 \mathrm{~cd}$ \\
\hline Rice -straw mulch & $4.8 \mathrm{bc}$ & $4.9 \mathrm{bc}$ & $6.8 \mathrm{a}$ & $7.3 \mathrm{a}$ \\
\hline Polythene mulch & $4.7 \mathrm{bc}$ & $5.6 \mathrm{ab}$ & $3.9 \mathrm{~cd}$ & $2.9 \mathrm{~d}$ \\
\hline SE+-1.28 & \multicolumn{5}{|l|}{} \\
\hline
\end{tabular}

Means followed by the same letter(s) within a column and treatment set are not significantly different when using DMRT $(\mathrm{P}=0.05), \mathrm{NS}=$ Not significant 